\title{
Fractional Crystallization and Crustal Contamination of Doleritic and Trachytic Dykes Crosscutting the Cretaceous Sedimentary Basins from Figuil (North Cameroon) and Léré (South-Western Chad): Geodynamic Implications
}

\author{
Moussa Ngarena Klamadji ${ }^{*}$, Merlin Gountié Dedzo ${ }^{2}$, Rigobert Tchameni ${ }^{3}$, \\ Djamilatou Diddi Hamadjoda4, Pierre Christel Biakan à Nyotok ${ }^{4}$, Gervais Onana ${ }^{4}$
}

\author{
${ }^{1}$ Département des Sciences de la Vie et de la Terre, Faculté des Sciences Techniques et de la Technologie, Université de Pala, \\ Pala, Tchad \\ ${ }^{2}$ Department of Life and Earth Sciences, High Teachers' Training College, University of Maroua, Maroua, Cameroon \\ ${ }^{3}$ Department of Earth Sciences, Faculty of Science, University of Ngaoundéré, Ngaoundéré, Cameroon \\ ${ }^{4}$ Department of Earth Sciences, Faculty of Sciences, University of Maroua, Maroua, Cameroon \\ Email: ${ }^{\star}$ klamadjimoussa@yahoo.fr
}

How to cite this paper: Klamadji, M.N. Gountié Dedzo, M, Tchameni, R., Diddi Hamadjoda, D., Biakan à Nyotok, P. C., \& Onana, G. (2021). Fractional Crystallization and Crustal Contamination of Doleritic and Trachytic Dykes Crosscutting the Cretaceous Sedimentary Basins from Figuil (North Cameroon) and Léré (South-Western Chad): Geodynamic Implications. Journal of Geoscience and Environment Protection, 9, 190-210.

https://doi.org/10.4236/gep.2021.912012

Received: August 12, 2021

Accepted: December 27, 2021

Published: December 30, 202

Copyright ( 2021 by author(s) and Scientific Research Publishing Inc. This work is licensed under the Creative Commons Attribution International License (CC BY 4.0).

http://creativecommons.org/licenses/by/4.0/ (c) (i) Open Access

\begin{abstract}
Magmatism in the Cretaceous sedimentary basins of the Figuil and Léré regions constitutes one of the fundamental parameters in the reconstruction of the history of the Cretaceous sedimentary basins. The main objective of this paper is to constrain the petrogenetic processes of hypovolcanic rocks and to determine their geodynamic context of emplacement. The petrographic study of mafic hypovolcanic and trachytic rocks was carried out under a polarizing microscope on thin sections. For the geochemical study, the major oxides and some trace elements were analyzed by ICP-AES. Trace and rare earth elements were analyzed by ICP-MS. The dolerites of the Cretaceous sedimentary basins are composed of dykes of amphibole bearing dolerites, biotite and pyroxene bearing dolerite, pyroxene bearing dolerites and trachytes. The dykes are in the order of 20 to $100 \mathrm{~m}$ wide by several kilometers long and oriented from $\mathrm{N} 23^{\circ} \mathrm{E}$ to $\mathrm{N} 90^{\circ} \mathrm{E}$. The textures of these rocks are sub-ophitic to intergranular for dolerites and trachytic for evolved rocks (trachytes). The geochemical study shows that the dolerites are basaltic in composition with alkaline to subalkaline character. The sampled dykes have an evolution dominated by fractional with the minor impact of the crustal assimilation characterized by low $\mathrm{Rb} / \mathrm{Y}$ ratios for dolerites $(0.36-0.97)$ and high values of $\mathrm{Rb} / \mathrm{Y}$ for the Pan-African granitoids' samples (1.95 - 4.01). The nature of doleritic and trachytic magma sources is supported by their $(\mathrm{Tb} / \mathrm{Yb}) \mathrm{N}>1.9(1.91-3.79)$
\end{abstract}


and $\mathrm{Dy} / \mathrm{Yb}>2(2.32$ - 3.50) ratios of most samples, which suggests melting in a garnet-bearing mantle. Concerning the geodynamic context of the studied rocks, doleritic samples are classified as within-plate tholeiite and volcanic arc basalt, and within-plate alkali basalts.

\section{Keywords}

Dolerites, Trachyte, Sedimentary Basins, Continental Tholeiites, Figuil and Léré

\section{Introduction}

Magmatic intrusions usually made up of basic and ultrabasic rocks generally exploit fracturing networks to set up (Srivastava, 2011; Silpa et al., 2021; Huang et al., 2021). The geochemical characteristics of these magmatic intrusions provide, on the one hand, elements in the reconstruction of regional geodynamic contexts, synchronous for their establishment and, on the other hand, information on the source zones of the magmas (Halls, 1987). In Central Africa, magmatic intrusions of a doleritic nature are represented by two subsets: the dolerites of the extension basins and the so-called continental tholeiite dolerites. Dolerites from extension basins have been identified in Anambra in Nigeria (Coulon et al., 1996) and in northern Cameroon, in the region of Mayo Oulo-Léré and Babouri-Figuil (Ngounouno et al., 2001). The formation of basic to intermediate intrusions which very often outcrop in dykes and sills is considered to be a direct consequence of tectonic events that have affected the Pan-African basement (Toteu et al., 1987, 1990). In Cameroon, mafic dykes have been studied in southern Cameroon in many localities: 1) Biden in the south-east of Ngaoundéré (Vicat et al., 2001);2) Mayo Oulo-Léré (Ngounouno et al., 2001); 3) Banganté, Maham, Kendem, Dschang, Bangoua and Manjo (Tchouankoué et al., 2012, 2014); 4) Mbaoussi (Nkouandou et al., 2016); 5) Likok (Nkouandou et al., 2015); 6) Mongo in Central Chad (Nkouandou et al., 2017); 7) Temte (Poli) in North Cameroon (Atour et al., 2020); 8) Figuil and Léré (Far North Cameroon and SW of Chad) where these dykes intersect the Pan-African basement (Klamadji et al., 2020). In the Cretaceous sedimentary basins of the study area, straddling Cameroon and Chad (Figuil and Léré), basic intrusions of a doleritic nature have so far not been the subject of a detailed petrological study. The main objective of this study is to constrain the petrogenetic processes of these hypovolcanic rocks and to determine their geodynamic context using major and trace elements' data.

\section{Geological Background of Cretaceous Sedimentary Basins from Figuil and Léré (Mayo-Oulo-Léré)}

The Mayo Oulo-Léré basin, in which the dykes studied are located, is a semigraben with an asymmetric syncline structure belonging to the intracontinental basins of North Cameroon (Dejax \& Brunet, 1996). It is made up of the other small sedimentary basins (Babouri-Figuil, Hama-koussou and Koum) with Wea- 
lidian facies of the Lower Cretaceous whose history is linked to the formation of the Bénoué ditch. The main geological units in the area include the Precambrian basement dated Meso to Neo-Proterozoic between -700 to $-1000 \mathrm{Ma}$ (Dawaï, 2014); a thick sedimentary layer dated from the Lower Cretaceous which lies in discordance on the Precambrian basement and post-Pan-African magmatic occurrences (Schwoerer, 1965). The magmatic rocks of Léré and Figuil intersected a basement of Middle to Upper Proterozoic age, covered with sediments of Lower Cretaceous age which were deposited in the two basins of $1000 \mathrm{~km}^{2}$ surface (Schwoerer, 1965). The sedimentary cover formations (Figure 1 and Figure 2)

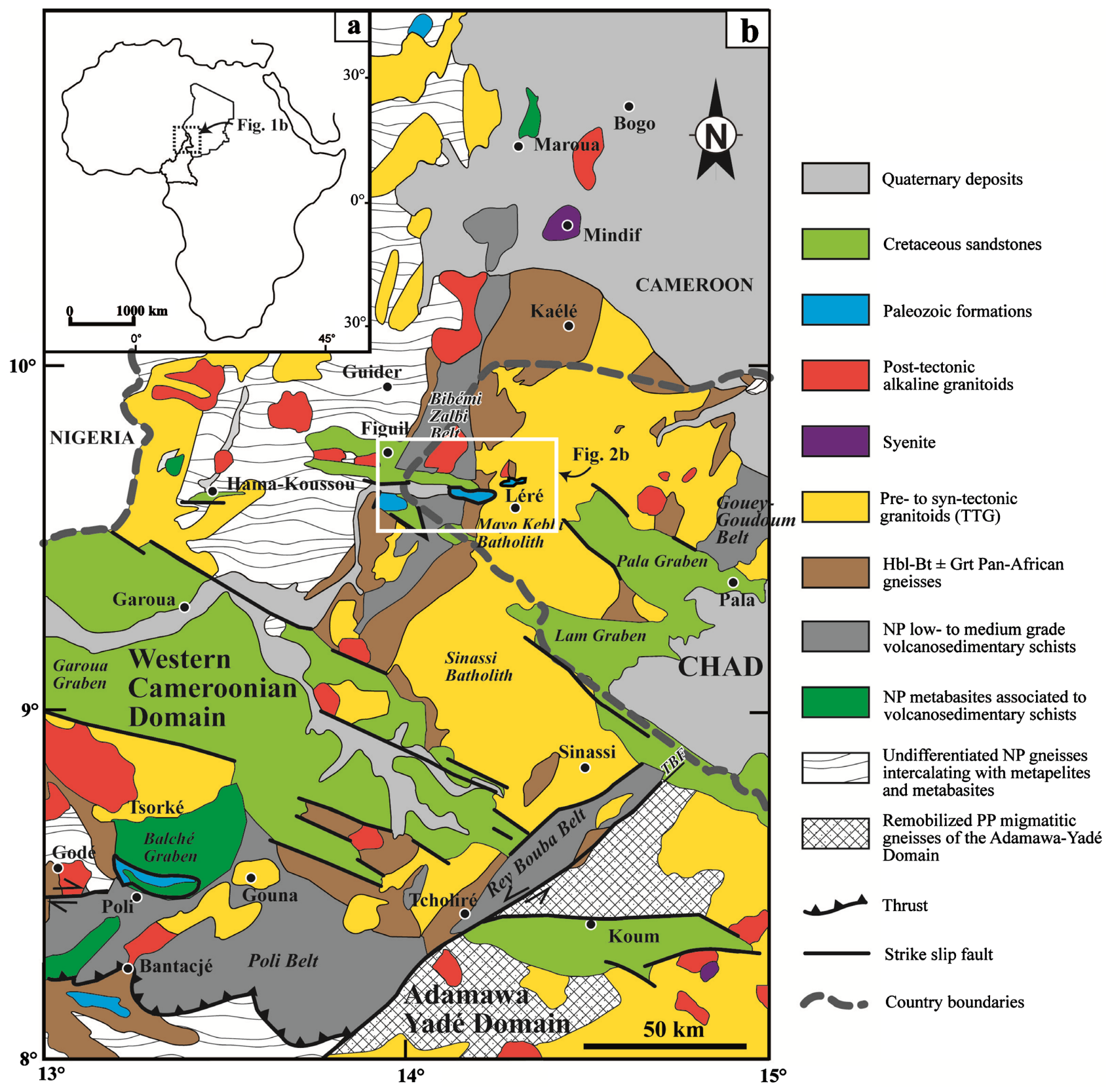

Figure 1. (a) Location of Cameroon and Chad in Africa. (b) Geological map of North Cameroon and South West Chad (redrawn from (Bouyo et al., 2015)). TBF: Tcholliré-Banyo fault; NP: Neoproterozoic; PP: Paleoproterozoic. 


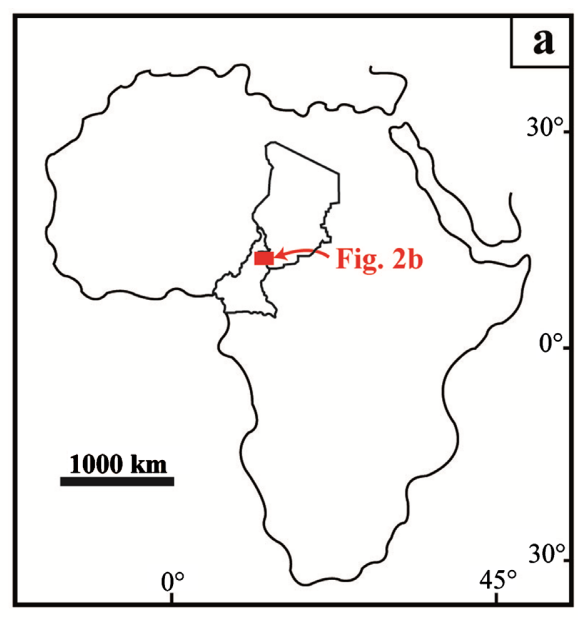

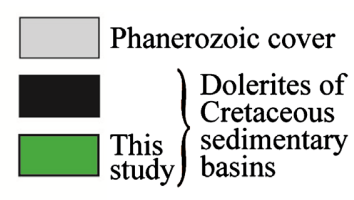
$\square$ Dolerites of Pan-African

$\checkmark$ Faults

Country boundary

FSZ: Figuil shear zone

ZSZ: Zalbi shear zone

LSZ: Léré shear zone

- 5 Sampling point for geochemical analysis

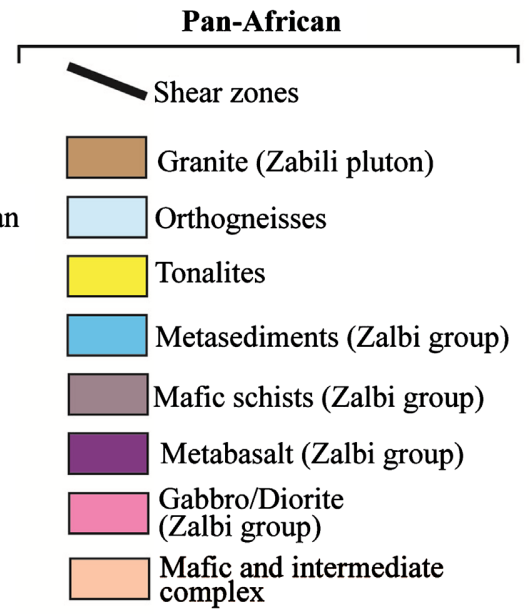

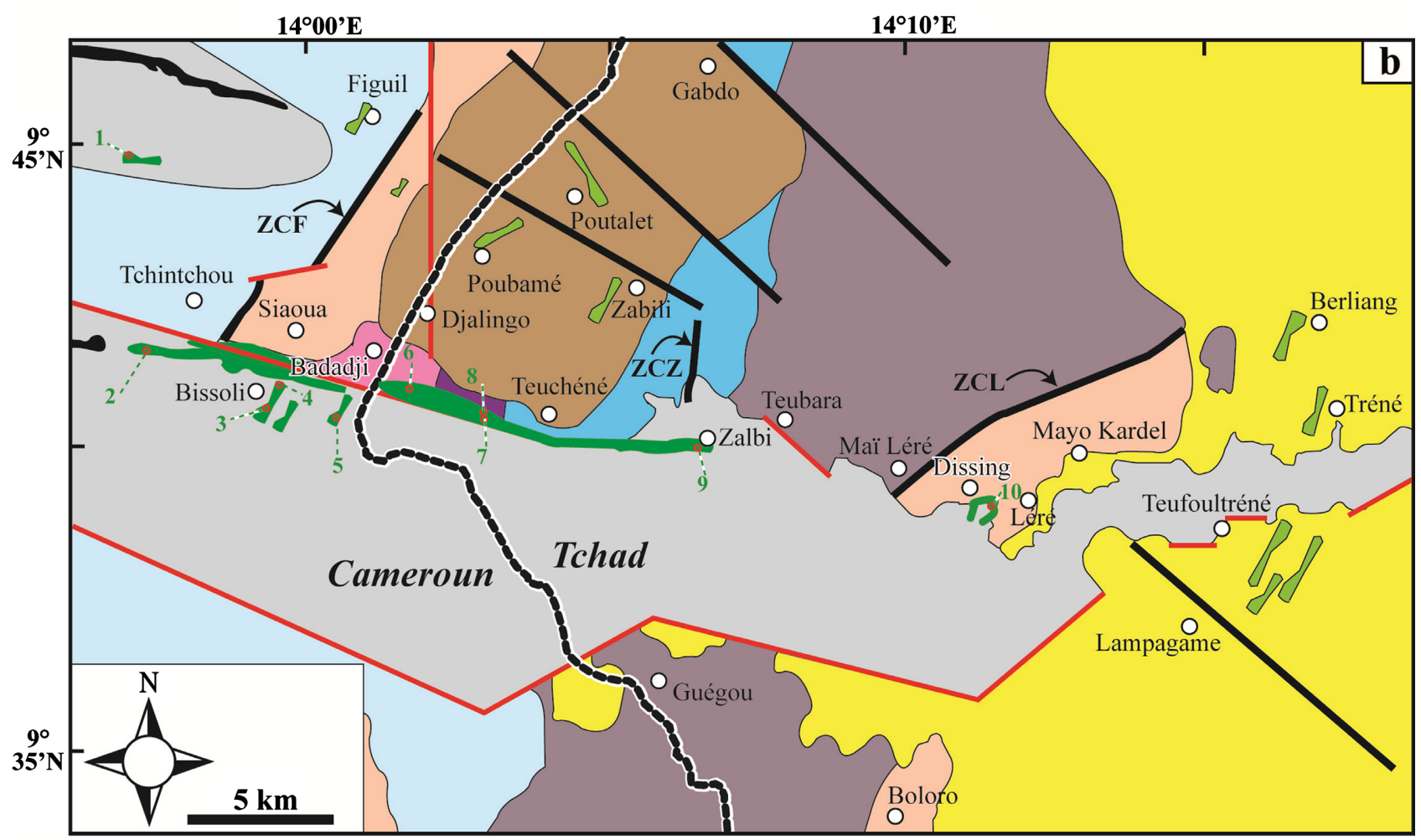

Figure 2. Geological sketch map of Figuil-Léré area (modified from (Isseini et al., 2012)). 1: FmsM1; 2: FtgM3; 3: FbiM1; 4: FbiM2; 5: FbaM1; 6: DjM2; 7: T2M1; 8: T2M3; 9: ZaM1; 10: DiM3.

consist of two series: 1) the Léré series in the western extension of Lake Léré, and 2) the Lamé series west of Pala in the region by Lamé (Wacrenier, 1952). In the South and South-East, these formations are made up of the tertiary ferruginous sandstone of Pala (Maurin \& Guiraud, 1990).

The Léré series contains formations from the Lower Cretaceous (AptianAlbian). These formations are made up of thin thickness conglomerates, surmounted by coarse sandstone more or less arkosic and fine and tender sandstone, sometimes with ripple marks (elongated ridge forming a relief) alternating with greenish marls which contain some traces of limestone. Dolerite sills are 
interbedded there. These conglomerates, arkosic sandstones alternate with schists. In Figuil (North Cameroon), bituminous shales occupy a graben which continues east of Lake Léré and develops on Cameroonian territory.

The Lamé series is made up of formations of marine and continental origin from the Upper Cretaceous (Albian-Cenomanian) (Maurin \& Guiraud, 1990). The formations consist of coarse conglomerates surmounted by arkoses, sandstones, limestone sandstones, marls, clays and lenses with lumachelles of lagoon origin. The conglomerates found along the border of the basin, north of Pala contain pebbles and boulders up to $30 \mathrm{~cm}$ in diameter. The limestones appearing mainly between Baoaré and Louga, near the Cameroon border, provided molluscs (Gastropods). It is crosscut by veins and laccolites of basalt and olivine bearing dolerites.

\section{Sampling and Analytical Methods}

A total of seven (7) samples were collected from the different dykes outcropping in the area. They were then carefully cleaned and, labeled. The preparation of thin sections was realized at Key laboratory Coalbeb Methane Resource and Reservoir Training in China. These samples were then also sent to Bureau Veritas Mineral Laboratories in Vancouver, Canada for major and trace element geochemical analyzes according to the techniques described by Klamadji et al. (2020). Rock powder of each sample $(0.2 \mathrm{~g})$ was added to lithium metaborate/lithium tetraborate flux $(0.90 \mathrm{~g})$, well mixed and fused in a furnace at $1000^{\circ} \mathrm{C}$. The resulting melt was then cooled and dissolved in $100 \mathrm{ml}$ of $4 \%$ nitric acid and $2 \%$ hydrochloric acid. This solution was then analyzed by a combination of ICP-MS (Inductively Coupled Plasma-Mass Spectrometry) and ICP-AES (inductively-coupled plasma-atomic emission spectrometry) to determine major and trace element compositions of the samples. The obtained results were corrected for spectral inter-element interferences. Oxide concentration was calculated from the determined elemental concentration and the result was reported in that format. Loss on ignition (LOI) was measured by weight difference after ignition at $1000^{\circ} \mathrm{C}$. To certify data quality ( $95 \%$ confidence level) and to calibrate the equipment for optimal precision, a replicate, standard and blank was measured. For the major oxides, the analytical uncertainties were about $0.01 \mathrm{wt} \%$, apart from $\mathrm{Fe}_{2} \mathrm{O}_{3}$ (0.04\%). The detection limits for trace elements were variable as follow (in ppm): Ni (20); V (8); Ba, Sc, Be, Sn (1); Ga, Sr, W (0.5); Nd (0.3); Co, Th (0.2); Cs, Hf, $\mathrm{Nb}, \mathrm{Rb}, \mathrm{Ta}, \mathrm{U}, \mathrm{Zr}, \mathrm{Y}, \mathrm{La}, \mathrm{Ce}(0.1)$; Sm, Gd, Dy, Yb (0.05); Er (0.03); Pr, Eu, Ho (0.02); $\mathrm{Tb}, \mathrm{Tm}, \mathrm{Lu}(0.01)$. Results of petrography and geochemistry analysis are presented in Table 1 and Table 2.

\section{Results}

\subsection{Petrography}

The hypovolcanic and volcanic dykes that are the subject of this work are dolerites and trachytes with length varying from 0.38 to $9.5 \mathrm{~km}$ and width ranging 
Table 1. Petrographic and structural characteristics of the studied dykes.

\begin{tabular}{ccccc}
\hline & $\mathrm{AD}$ & $\mathrm{BPD}$ & $\mathrm{PD}$ & Trachyte \\
\hline Orientation & - & $\mathrm{N} 23^{\circ} \mathrm{E}-\mathrm{N} 45^{\circ} \mathrm{E}$ & $\mathrm{N} 30^{\circ}-60^{\circ} \mathrm{E}$ & $\mathrm{N} 90^{\circ} \mathrm{E}$ \\
Width & $30-35 \mathrm{~m}$ & $50-100 \mathrm{~m}$ & $75-100 \mathrm{~m}$ & $45-75 \mathrm{~m}$ \\
Length & $38-40 \mathrm{~m}$ in diameter & $9-9.5 \mathrm{~km}$ & $5-7 \mathrm{~km}$ & $3-4 \mathrm{~km}$ \\
& $\mathrm{Pl}+\mathrm{Cpx}+\mathrm{Amp}+\mathrm{Afs}+$ & $\mathrm{Pl}+\mathrm{Afs}+\mathrm{Cpx}+$ & $\mathrm{Pl}+\mathrm{Afs}+\mathrm{Cpx}$ & $\mathrm{Pl}+\mathrm{Sa}+\mathrm{Bt}$ \\
Mineralogy & $\mathrm{Bt}+\mathrm{Opq}+\mathrm{Ap}+\mathrm{Ep}+$ & $\mathrm{Bt}+\mathrm{Qtz}+\mathrm{Opq}+$ & $+\mathrm{Qtz}+\mathrm{Opq}+$ & $+\mathrm{Opq}$ \\
& $\mathrm{Chl}+\mathrm{Ttn}$ & $\mathrm{Ep}+\mathrm{Chl}$ & $\mathrm{Ep}+\mathrm{Ch}$ & $\mathrm{Ep}+\mathrm{Chl}$ \\
\hline
\end{tabular}

$\mathrm{AD}$ : amphibole bearing dolerites; BPD: biotite and pyroxene bearing dolerites; PD: pyroxene bearing dolerites. Cpx: clinopyroxene; Pl: plagioclase; Opq: opaque; Amp: amphibole; Bt: biotite; Afs: alkali feldspar; Sa: sanidine; Qtz: quartz; Ap: apatite; Ttn: titanite; Ep: epidote; Chl: chlorite.

Table 2. Whole-rock major and trace element composition of the Figuil and Léré dykes.

\begin{tabular}{|c|c|c|c|c|c|c|c|}
\hline Sample ID & DiM3 & ZaM1 & T2M3 & $\mathrm{T} 2 \mathrm{M} 1$ & $\mathrm{DjM} 2$ & FtgM3 & FmsM1 \\
\hline Rock type & $\mathrm{AD}$ & $\mathrm{BPD}$ & BPD & $\mathrm{BPD}$ & BPD & $\mathrm{PD}$ & Trachyte \\
\hline \multicolumn{8}{|l|}{ Major (Wt\%) } \\
\hline $\mathrm{SiO}_{2}$ & 48.25 & 49.8 & 50.01 & 52.59 & 49.95 & 51.79 & 62.05 \\
\hline $\mathrm{TiO}_{2}$ & 2.63 & 1.67 & 1.76 & 1.71 & 1.86 & 1.96 & 0.84 \\
\hline $\mathrm{Al}_{2} \mathrm{O}_{3}$ & 14.44 & 14.36 & 14.16 & 14.72 & 14.62 & 14 & 16.74 \\
\hline $\mathrm{Fe}_{2} \mathrm{O}_{3}$ & 12.05 & 11.11 & 11.22 & 10.62 & 10.68 & 11.49 & 4.23 \\
\hline $\mathrm{MnO}$ & 0.16 & 0.14 & 0.15 & 0.14 & 0.15 & 0.15 & 0.05 \\
\hline $\mathrm{MgO}$ & 6.82 & 6.95 & 6.89 & 5.4 & 6.04 & 6.45 & 1.8 \\
\hline $\mathrm{CaO}$ & 8.97 & 9.26 & 9.24 & 8.9 & 9.84 & 8.38 & 2.44 \\
\hline $\mathrm{Na}_{2} \mathrm{O}$ & 3.66 & 2.43 & 2.64 & 3.34 & 2.49 & 3.06 & 5.97 \\
\hline $\mathrm{K}_{2} \mathrm{O}$ & 1.2 & 0.3 & 0.32 & 0.59 & 0.37 & 0.48 & 3.61 \\
\hline $\mathrm{P}_{2} \mathrm{O}_{5}$ & 0.52 & 0.15 & 0.15 & 0.17 & 0.16 & 0.19 & 0.38 \\
\hline LOI & 0.9 & 3.5 & 3.2 & 1.6 & 3.6 & 1.7 & 1.5 \\
\hline Total & 99.69 & 99.77 & 99.77 & 99.79 & 99.78 & 99.76 & 99.7 \\
\hline $\mathrm{Mg \#}$ & 56 & 58.4 & 58 & 53.3 & 56 & 55.8 & 48.9 \\
\hline \multicolumn{8}{|l|}{ Traces (ppm) } \\
\hline $\mathrm{Sc}$ & 18.0 & 20.0 & 21.0 & 22.0 & 24.0 & 21.0 & 4.0 \\
\hline $\mathrm{Be}$ & 3.0 & $<1$ & $<1$ & $<1$ & 2.0 & 1.0 & 5.0 \\
\hline $\mathrm{V}$ & 190.0 & 168.0 & 178.0 & 196.0 & 199.0 & 171.0 & 36.0 \\
\hline Co & 43.5 & 40.3 & 39.7 & 33.1 & 35.8 & 37.3 & 10.1 \\
\hline $\mathrm{Ni}$ & 94.0 & 122.0 & 119.0 & 50.0 & 54.0 & 121.0 & 30.0 \\
\hline $\mathrm{Cr}$ & 290 & 360 & 390 & 120 & 120 & 360 & 50 \\
\hline $\mathrm{Ga}$ & 19.8 & 17.6 & 17.2 & 20.3 & 18.3 & 19.3 & 25.2 \\
\hline
\end{tabular}


Continued

\begin{tabular}{|c|c|c|c|c|c|c|c|}
\hline $\mathrm{Rb}$ & 20.3 & 6.3 & 6.3 & 11.0 & 7.2 & 8.1 & 70.2 \\
\hline $\mathrm{Sr}$ & 761.8 & 342.9 & 379.1 & 301.5 & 313.9 & 325.9 & 1099.1 \\
\hline $\mathrm{Y}$ & 20.9 & 17.4 & 17.4 & 20.8 & 17.7 & 22.2 & 10.0 \\
\hline $\mathrm{Zr}$ & 179.9 & 81.9 & 79.0 & 119.0 & 85.1 & 119.6 & 557.8 \\
\hline $\mathrm{Nb}$ & 36.7 & 7.3 & 7.3 & 10.9 & 9.5 & 8.4 & 50.2 \\
\hline $\mathrm{Sn}$ & 1.0 & $<1$ & $<1$ & $<1$ & $<1$ & $<1$ & 1.0 \\
\hline Cs & 0.5 & 0.3 & 0.1 & $<0.1$ & $<0.1$ & 0.2 & 0.5 \\
\hline $\mathrm{Ba}$ & 498.0 & 81.0 & 72.0 & 119.0 & 84.0 & 185.0 & 708.0 \\
\hline $\mathrm{La}$ & 24.2 & 6.5 & 6.5 & 10.7 & 7.6 & 9.2 & 55.2 \\
\hline $\mathrm{Ce}$ & 48.9 & 14.7 & 14.4 & 22.5 & 17.0 & 19.9 & 99.1 \\
\hline $\operatorname{Pr}$ & 6.0 & 2.1 & 2.0 & 2.9 & 2.3 & 2.7 & 9.9 \\
\hline $\mathrm{Nd}$ & 26.1 & 9.5 & 9.4 & 13.9 & 10.9 & 13.5 & 32.8 \\
\hline $\mathrm{Sm}$ & 6.1 & 2.9 & 3.0 & 3.6 & 3.0 & 3.9 & 5.5 \\
\hline $\mathrm{Eu}$ & 2.2 & 1.2 & 1.2 & 1.4 & 1.3 & 1.5 & 1.7 \\
\hline $\mathrm{Gd}$ & 6.3 & 3.9 & 4.0 & 4.9 & 4.1 & 5.1 & 4.1 \\
\hline $\mathrm{Tb}$ & 0.9 & 0.6 & 0.6 & 0.7 & 0.6 & 0.8 & 0.5 \\
\hline Dy & 4.7 & 3.7 & 3.5 & 4.3 & 3.6 & 4.4 & 2.1 \\
\hline Ho & 0.8 & 0.7 & 0.7 & 0.8 & 0.7 & 0.8 & 0.3 \\
\hline $\mathrm{Er}$ & 2.1 & 1.9 & 1.8 & 2.2 & 1.9 & 2.4 & 0.8 \\
\hline $\mathrm{Tm}$ & 0.3 & 0.2 & 0.2 & 0.3 & 0.2 & 0.3 & 0.1 \\
\hline $\mathrm{Yb}$ & 1.6 & 1.4 & 1.4 & 1.7 & 1.4 & 1.9 & 0.6 \\
\hline $\mathrm{Lu}$ & 0.2 & 0.2 & 0.2 & 0.3 & 0.2 & 0.3 & 0.1 \\
\hline Hf & 4.3 & 2.3 & 2.3 & 3.0 & 2.3 & 3.1 & 12.0 \\
\hline $\mathrm{Ta}$ & 1.9 & 0.5 & 0.4 & 0.6 & 0.5 & 0.5 & 3.5 \\
\hline W & 0.7 & $<0.5$ & 0.6 & $<0.5$ & $<0.5$ & 0.6 & 1.4 \\
\hline Th & 2.8 & 0.7 & 0.6 & 1.0 & 0.8 & 0.8 & 9.9 \\
\hline $\mathrm{U}$ & 0.9 & 0.2 & 0.2 & 0.3 & 0.2 & 0.2 & 2.9 \\
\hline $\mathrm{Eu} / \mathrm{Eu}^{*}$ & 1.08 & 1.09 & 1.06 & 1.02 & 1.13 & 1.03 & 1.09 \\
\hline $\mathrm{Nb} / \mathrm{Nb}^{*}$ & 1.50 & 1.15 & 1.25 & 1.12 & 1.30 & 1.04 & 0.72 \\
\hline
\end{tabular}

$\mathrm{AD}$ : amphibole bearing dolerites; $\mathrm{BPD}$ : biotite and pyroxene bearing dolerites; PD: pyroxene bearing dolerites.

from 30 to $100 \mathrm{~m}$ (Table 1 ). The petrographic study reveals mineral assemblage characteristics of dolerites and trachyte. For instance, we have assemblages of plagioclase, clinopyroxene, amphibole, alkali feldspar, quartz, biotite, oxides and apatite that characterize dolerites, and assemblage of plagioclase, sanidine, biotite and opaques minerals characterizing trachytes. All the rock-types present 
chlorites and epidotes as secondary minerals.

\subsubsection{Amphibole-Bearing Dolerites}

At Dissing, amphibole bearing dolerites (AD) outcrop in the form of decimetric and metric blocks with an annular shape of 38 to $40 \mathrm{~m}$ diameter. $\mathrm{AD}$ are characterized by a sub-ophitic texture. The minerals observed are phenocrysts and microcrystals of plagioclase, clinopyroxenes, amphiboles, biotite, alkali feldspars, opaque. Plagioclases which are the most abundant minerals appear in phenocrysts which are generally quite automorphic and in microliths (Figure 3(a)).
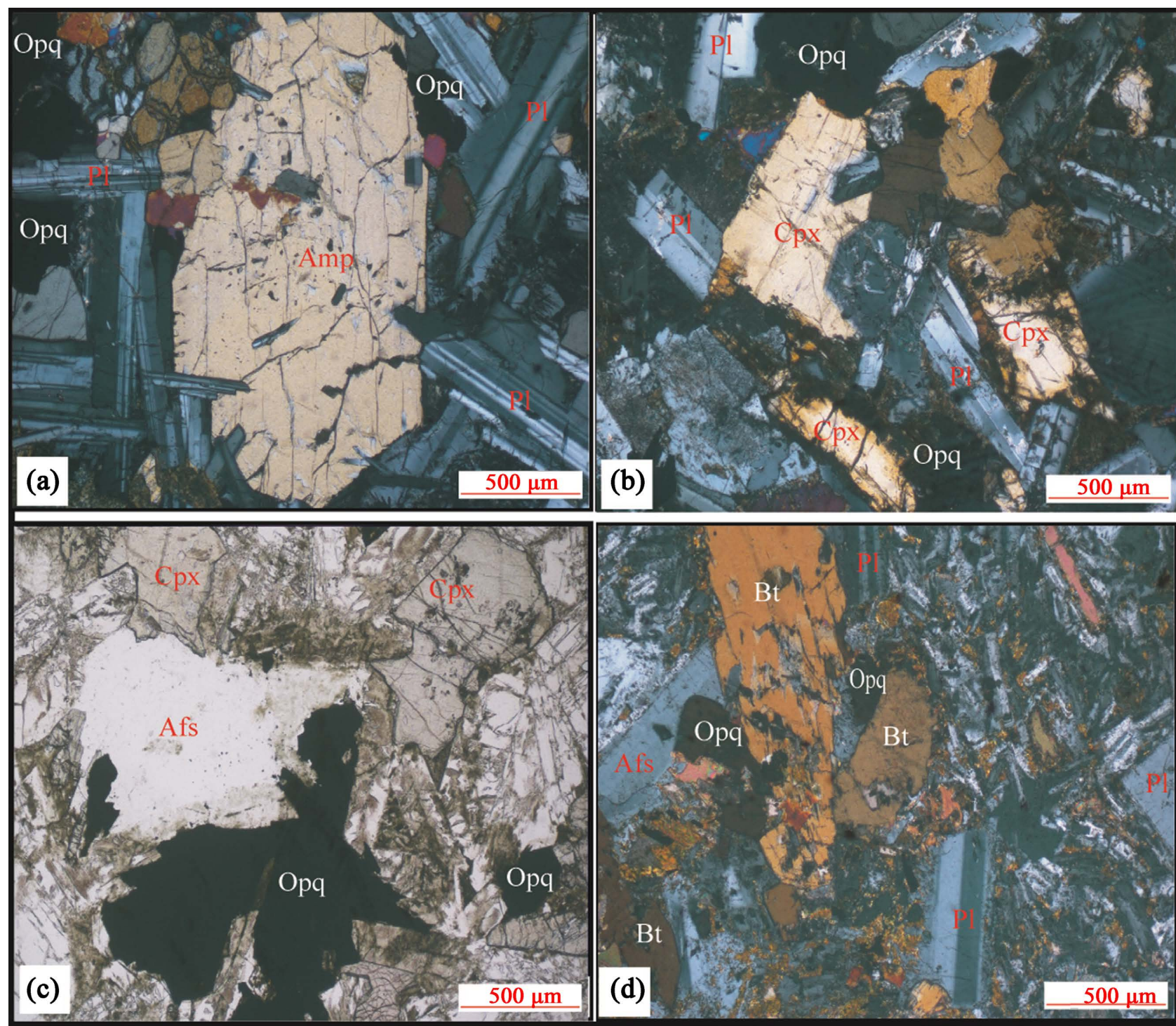

Figure 3. Photomicrograph highlighting the textures of hypovolcanic rocks. (a) Amphibole phenocryst in amphibole bearing dolerite; the arrangement of plagioclase phenocrysts around the amphibole phenocryst is observable. (b) Sub-ophitic texture of pyroxene bearing dolerites of Tchontchi-Golombé showing the damouritization of many sections of plagioclase. (c) Intergranular texture of Biotite and pyroxene bearing dolérites of Zalbi-Djalingo presenting an association of clinopyroxene, alkali feldspar and opaques phenocrysts sections. (d) porphyrtic texture of Mayo-Sorowel trachyte showing sanidine and biotite phenocrysts, and well-automorphic plagioclases in the matrix surrounded by sanidine microliths. Opq: Opaque minerals; Pl: Plagioclase; Amp: Amphibole; Cpx: Clinopyroxene; Bt: Biotite; Afs: Alkali feldspar. 
Inclusions of accessory minerals such as apatite and titanite have been observed in some sections.

\subsubsection{Pyroxene-Bearing Dolerites}

The pyroxene bearing dolerites (PD) of Tchintchou Golombe outcrop in the form of a rectilinear dyke oriented $\mathrm{N} 30^{\circ}-60^{\circ} \mathrm{E}$ (75 to $100 \mathrm{~m}$ width and $>5000 \mathrm{~m}$ long) with blocks of centimetric $(10$ to $24 \mathrm{~cm})$ to metric $(1.2 \times 2.8 \mathrm{~m})$ in diameter. The PD have a sub-ophitic texture (Figure $3(\mathrm{~b})$ ) and are made up of plagioclase, clinopyroxene, alkali feldspars, quartz, opaque minerals, epidote and chlorite. Damourite also occurs as a secondary mineral of plagioclase alteration (Figure 3(b)).

\subsubsection{Biotite and Pyroxene-Bearing Dolerites}

The biotite and pyroxene bearing dolerites (BPD) are observed in blocks (up to $3.7 \mathrm{~m}$ diameter) and flagstones at Zalbi, Teuchéné and Djalingo. They outcrop in the form of rectilinear dyke with $\mathrm{N} 23^{\circ} \mathrm{E}$ to $\mathrm{N} 45^{\circ} \mathrm{E}$ orientation, $50-100 \mathrm{~m}$ width and approximately $9.5 \mathrm{~km}$ long. Under microscope, the BPD show an intergranular texture (Figure $3(\mathrm{c})$ ) characterized by plagioclase, alkali feldspars, clinopyroxenes, biotite, quartz, opaque minerals, epidote and chlorite.

\subsubsection{Trachyte}

The trachyte also outcrops in the form of a rectilinear dyke (E-W) in the Cretaceous sedimentary basins of Babouri-Figuil and consists of large decimetric $(9 \times$ $12 \mathrm{dm})$ to metric $(1.5 \times 4.2 \mathrm{~m})$ blocks and flagstones. Porphyrtic texture of this trachytic dolerite is made up of alkali feldspar, plagiocalse and amphibole (Figure 3(d)).

\subsection{Geochemical Characterization}

\subsubsection{Major Elements Geochemistry}

The geochemical analyzes of the dolerite and trachyte samples are reported in Table 2.

Using the TAS diagram (Le Bas et al., 1986), dolerites are mainly basaltic, except the FmsM1 sample which is placed in the trachyte fields (Figure 4). The pyroxene bearing dolerites (PD) and biotite and pyroxene bearing dolerites (BPD) are sub-alkaline while trachyte and amphibole bearing dolerites (AD) are alkaline. The overall chemical composition is relatively homogeneous for dolerites: $48.25 \mathrm{wt} \%<\mathrm{SiO}_{2}<52.59 \mathrm{wt} \% ; 2.73 \mathrm{wt} \%<\mathrm{Na}_{2} \mathrm{O}+\mathrm{K}_{2} \mathrm{O}<4.86 \mathrm{wt} \% ; 10.62<$ $\mathrm{Fe}_{2} \mathrm{O}_{3}<12.05$ wt\%; $5.40 \mathrm{wt} \%<\mathrm{MgO}<6.95 \mathrm{wt} \% ; 1.67 \%<\mathrm{TiO}_{2}<2.63 \mathrm{wt} \% ; 14$ $\mathrm{wt} \%<\mathrm{Al}_{2} \mathrm{O}_{3}<14.72 \mathrm{wt} \%$.

AS suggested by the $\mathrm{Th} / \mathrm{Ta}$ ratio $(1.40$ - 1.66) (Cabanis \& Thieblemont, 1988), these dolerites belong to the continental tholeiite series. In fact, in the AFM diagram (Irvine \& Baragar, 1971), all the dolerite samples are placed in the tholeiitic domain (Figure 5(a)) except for the trachyte sample which is found in the calc-alkaline field. Figure 5(b) and Figure 5(c) confirm the fact that studied dolerites have tholeiitic composition. The silica content is within 


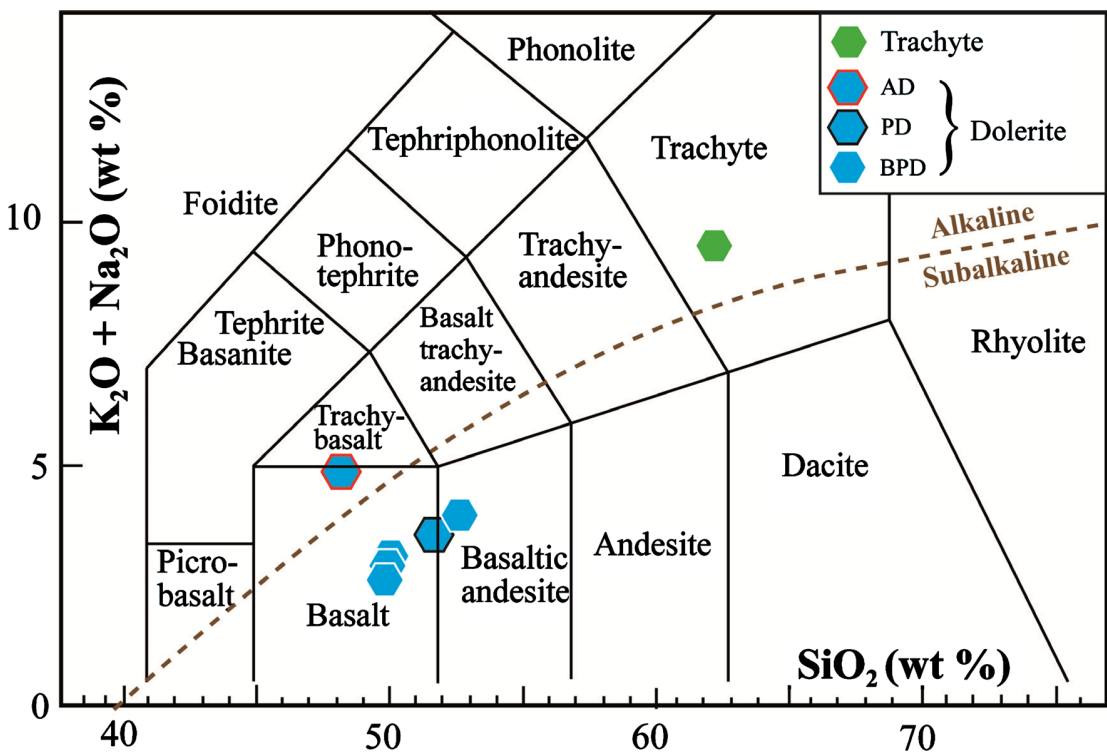

Figure 4. $\mathrm{K}_{2} \mathrm{O}+\mathrm{Na}_{2} \mathrm{O}$ versus $\mathrm{SiO}_{2}$ classification diagram (after (Le Bas et al., 1986)); the alkaline-subalkaline dividing line is from Irvine \& Baragar (1971). AD: amphibole bearing dolerites; PD: pyroxene bearing dolerites; BPD: biotite and pyroxene bearing dolerites.

the range of continental tholeiites described elsewhere (Carmichael et al., 1974): Karoo dolerites $\left(\mathrm{SiO}_{2}=50.6 \%\right.$ to $\left.53.6 \%\right)$, middle diabases of eastern North America North $\left(\mathrm{SiO}_{2}=51.1 \%\right)$, Columbia River basalts $\left(\mathrm{SiO}_{2}=50.0\right.$ to $\left.54.4 \%\right)$, Mayo Oulo-Léré and Babouri-Figuil dolerites $\left(\mathrm{SiO}_{2}=51.72 \%\right.$; (Ngounouno et al., 2001).

Harker diagrams for major elements present each oxide plotted against $\mathrm{MgO}$ wt\% (Figure 6). Negative correlations are observed for $\mathrm{Na}_{2} \mathrm{O}, \mathrm{K}_{2} \mathrm{O}, \mathrm{P}_{2} \mathrm{O}_{5}, \mathrm{Al}_{2} \mathrm{O}_{3}$ and $\mathrm{SiO}_{2}$ (Figures 6(a)-(e)) while positive correlations are visible for $\mathrm{Fe}_{2} \mathrm{O}, \mathrm{TiO}_{2}$, $\mathrm{MnO}$ and $\mathrm{CaO}$ (Figures 6(f)-(i)). These major element trends are compatible with an evolution of the magmas through the fractionation.

\subsubsection{Trace Elements Geochemistry}

Transitional metal like $\mathrm{Cr}, \mathrm{Co}, \mathrm{Ni}$, and $\mathrm{V}$ varies from one facies to another: amphibole bearing (Cr: 290 ppm; Co: 43.5 ppm; Ni: 94 ppm; V: 190 ppm), biotite and pyroxene bearing dolerites (Cr: 120 - 390 ppm; Co: 33.1 - 40.3 ppm; Ni: 50 122 ppm; V: 168 - 199 ppm), pyroxene bearing dolerites (Cr: 360 ppm; Co: 37.3 ppm; Ni: 121 ppm; V: 171 ppm). Trachyte has high levels $\mathrm{Ba}, \mathrm{Sr}, \mathrm{Rb}$ and Th, and low in $\mathrm{Sc}, \mathrm{V}, \mathrm{Ni}$ and $\mathrm{Co}$. The $\mathrm{Sc}, \mathrm{Ni}, \mathrm{Cr}$ and $\mathrm{Sr}$ contents increase with increasing $\mathrm{MgO}$ (Figures 7(a)-(d)) while the contents of $\mathrm{Rb}, \mathrm{Nb}$, $\mathrm{La}$ and $\mathrm{Zr}$ decrease with the increase of $\mathrm{MgO}$ (Figures 7(e)-(i)).

The rare earth elements spectra normalized to chondrites (Sun \& McDonough, 1989) (Figure 8(a)) of $\mathrm{AD}, \mathrm{BPD}$ and $\mathrm{PD}$ attest to the low fractionation of rare earth elements $(\Sigma \mathrm{REE}=45.95-130,32 \mathrm{ppm})$ for dolerites; $\Sigma \mathrm{REE}$ for trachyte is approximately $212.8 \mathrm{ppm}$. They also show a regular negative slope characterized by a low enrichment in LREE $((\mathrm{La} / \mathrm{Yb}) \mathrm{N}=3.33-65.99)$ similar to the fractiona- 
tion of HREE $((\mathrm{Gd} / \mathrm{Yb}) \mathrm{N}=2.22$ - 5.36). These rocks exhibit a slight positive Europium anomaly $\left(\mathrm{Eu} / \mathrm{Eu}^{*}=1.01-1.08\right)$. Primitive-mantle normalized (Sun \& McDonough, 1989) spider diagrams of the dolerites and trachyte are shown in Figure 8(b) and display a strongly negative slope characterized by a strong enrichment
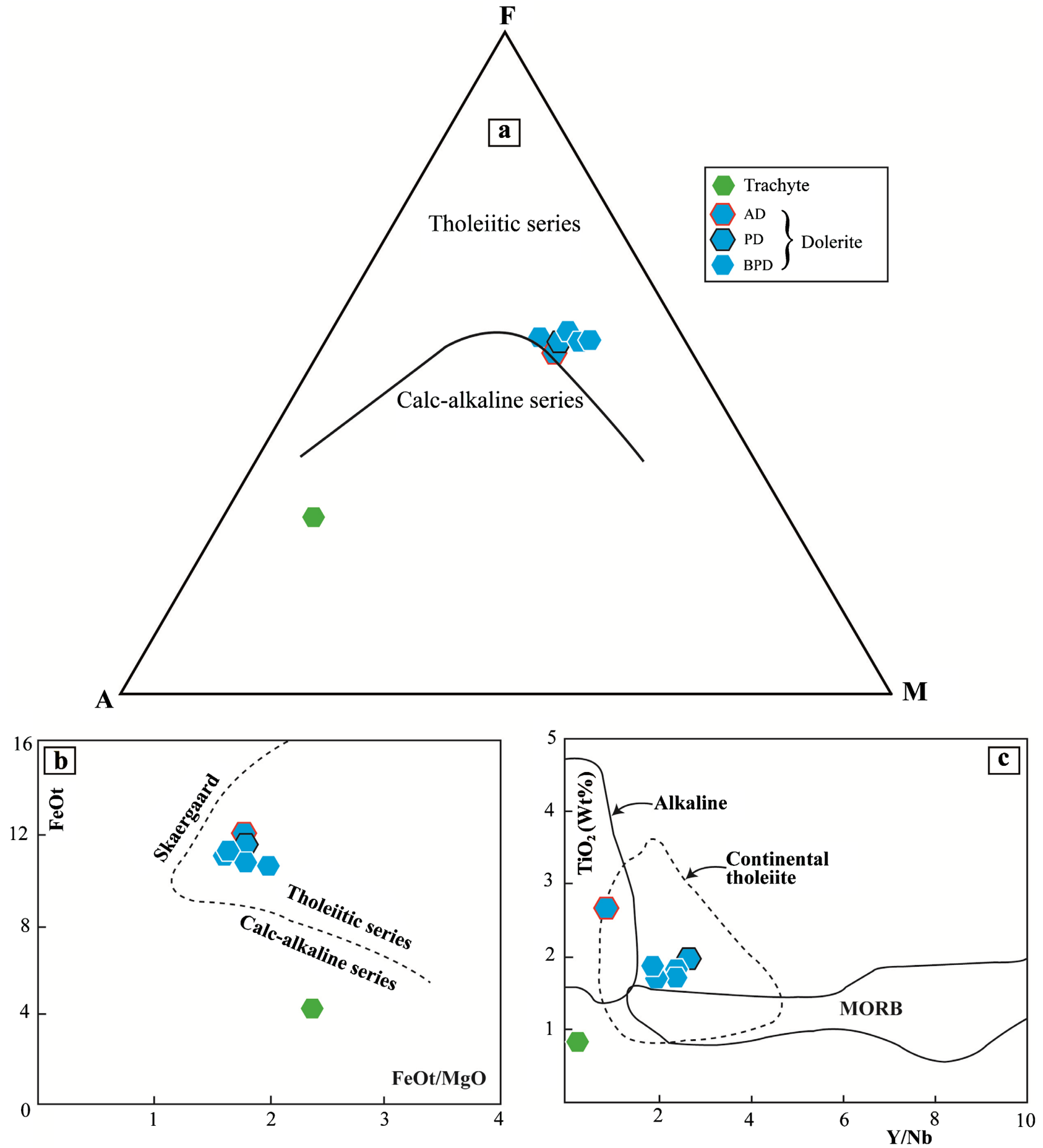

Figure 5. (a) AFM diagram of Ivrine \& Baragar (1971) showing geochemical affinities of the Figuil and Léré dolerites. A: $\mathrm{Na}_{2} \mathrm{O}+$ $\mathrm{K}_{2} \mathrm{O}$; F: FeOt; M: MgO. (b) FeOt versus (FeOt/MgO) diagram of Figuil and Léré rocks after Miyashiro (1974). (c) TiO ${ }_{2}$ versus $\mathrm{Y} / \mathrm{Nb}$ diagram of Figuil and Léré dolerite (after (Floyd \& Winchester, 1975)). 

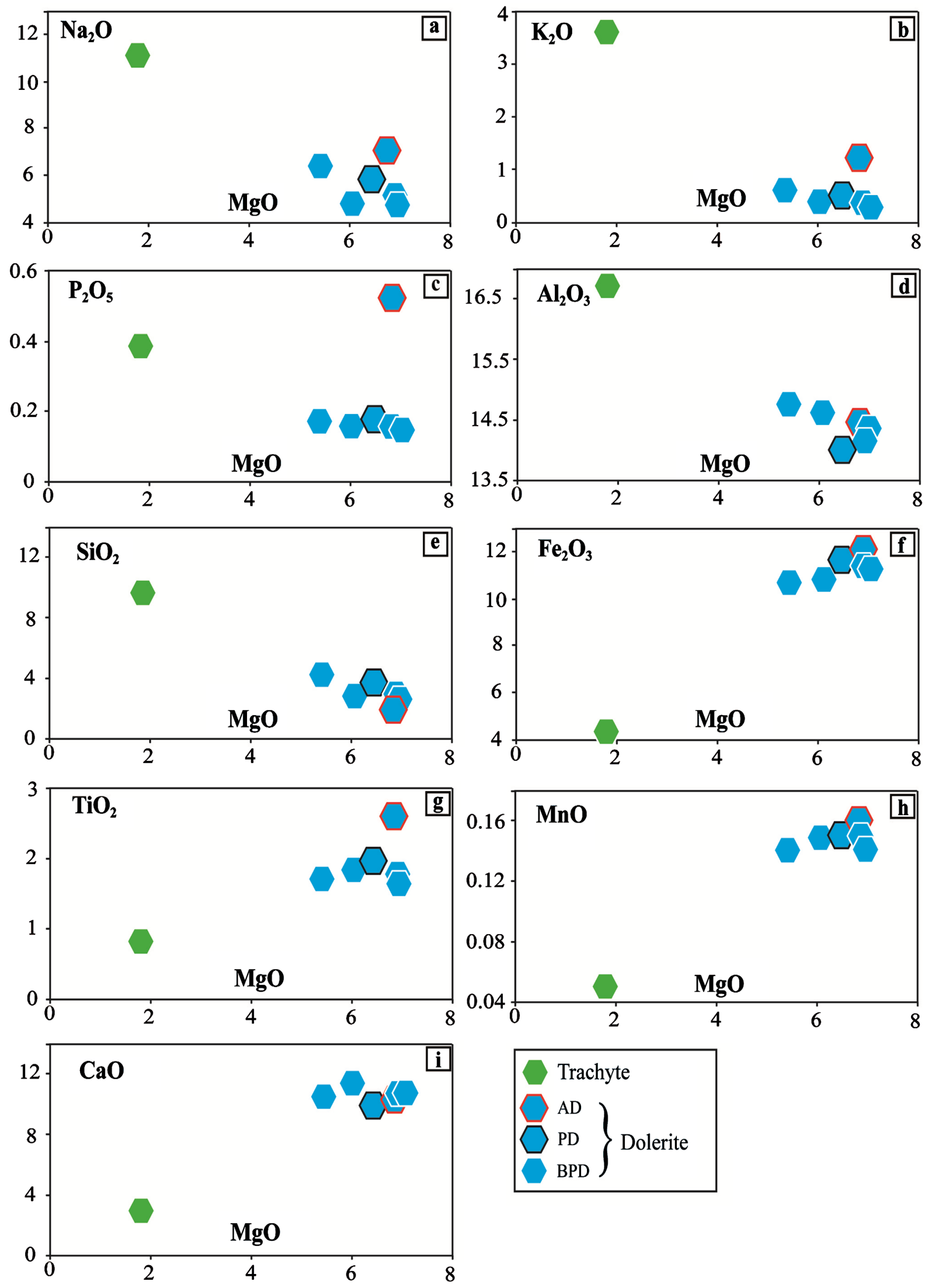

Figure 6. Harker diagrams of major elements versus $\mathrm{MgO}$. 

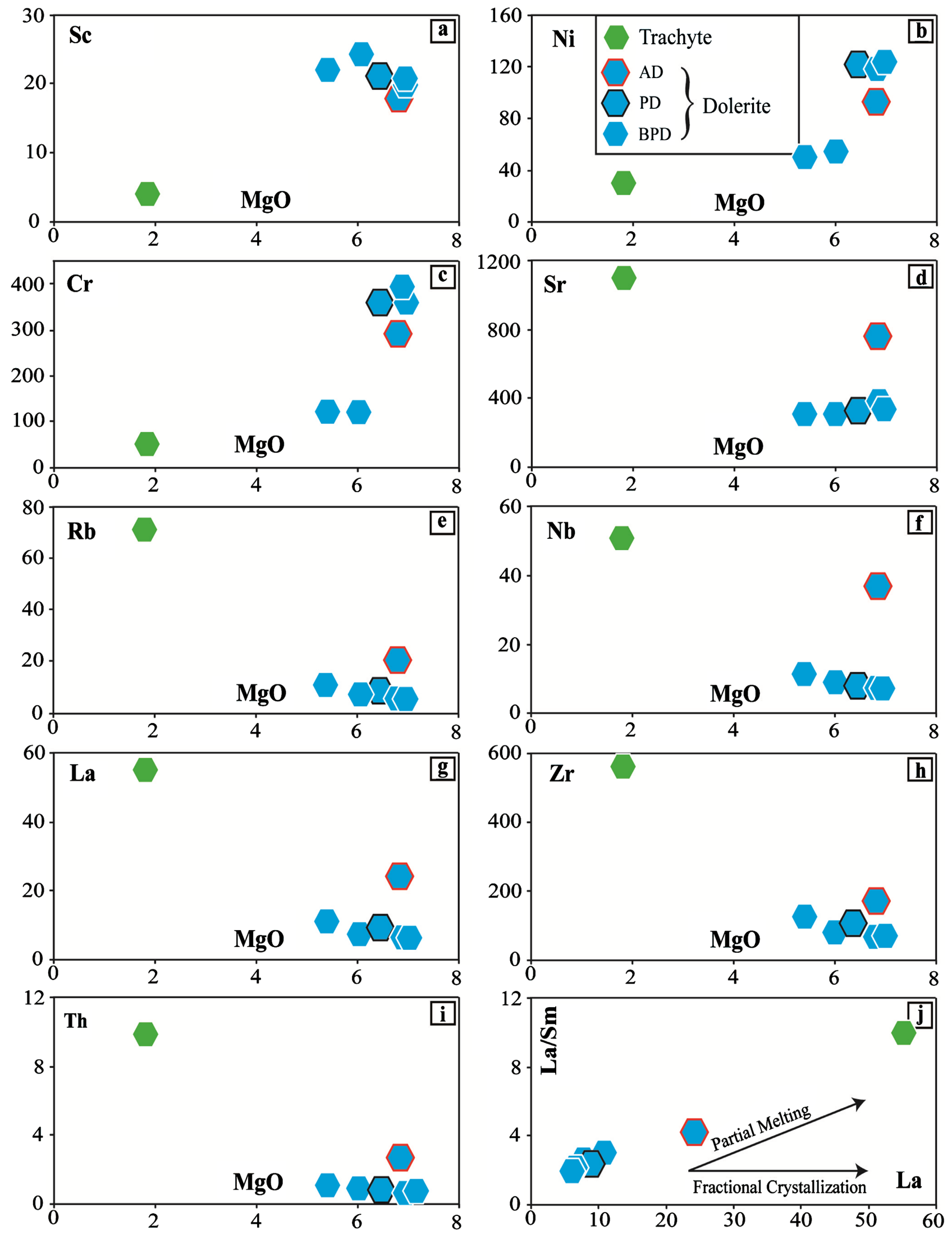

Figure 7. Harker diagrams of trace elements vs. MgO. 

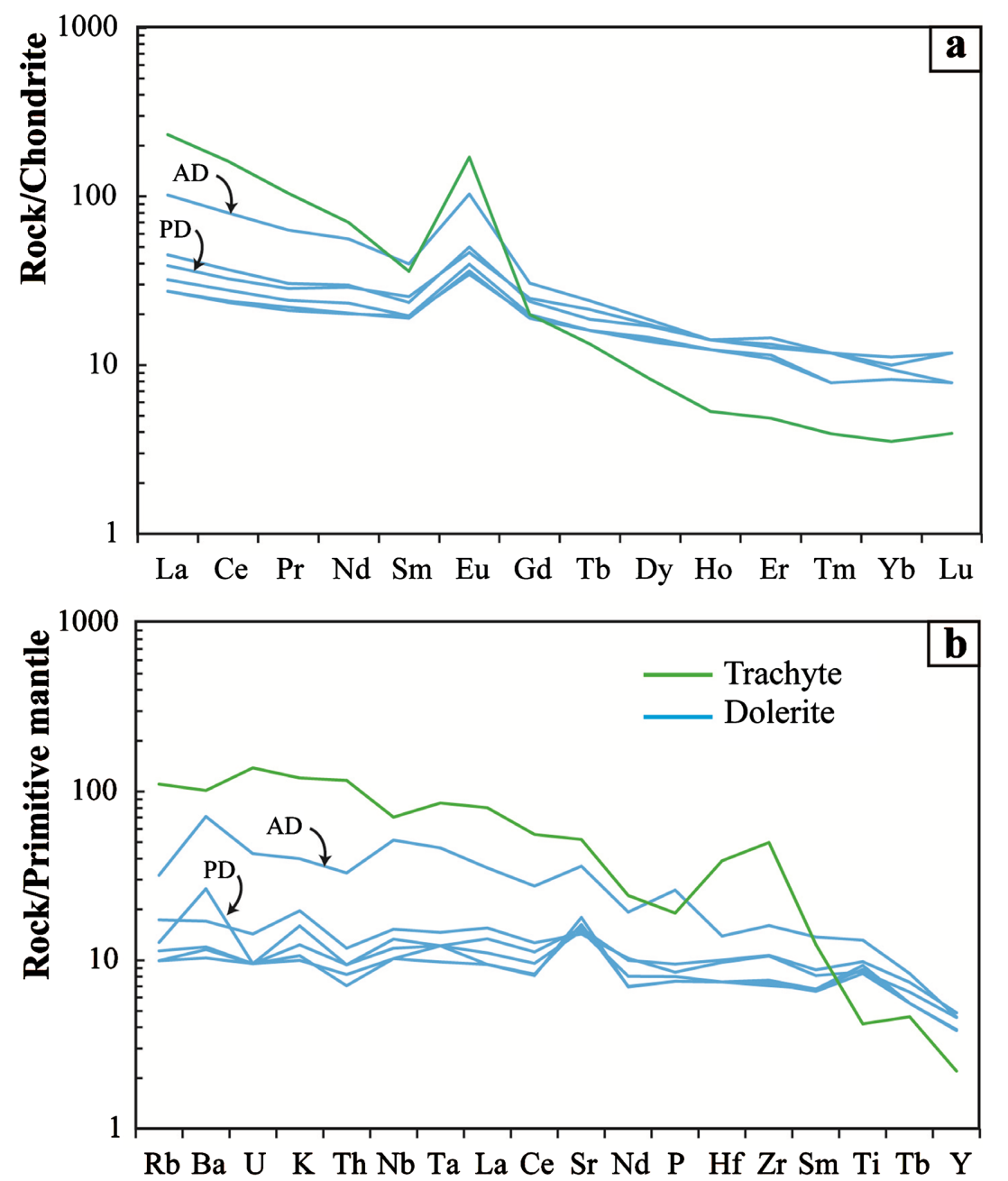

$\mathrm{AD}$ : amphibole bearing dolerites; PD: pyroxene bearing dolerites.

Figure 8. Chondrite (Sun \& McDounough, 1989), normalized REE patterns for dolerites (a) and Primitive Mantle (Sun \& McDounough, 1989), normalized multielement patterns for studied dolerites (b).

in LILE ( $\mathrm{Rb}, \mathrm{Ba}, \mathrm{Th})$ compared to HFSEs (Hf, Zr, Y). The dolerites show negative anomalies in $\mathrm{U}, \mathrm{Th}, \mathrm{Ce}$ and $\mathrm{Nd}$, and positive anomalies in $\mathrm{Ba}, \mathrm{K}, \mathrm{Nb}$ and $\mathrm{Sr}$.

\section{Discussion}

\subsection{Fractional Crystallization}

The major and trace elements systematics together with the petrographic observations of the studied samples suggest important level of continuous crystallization of mineral phases from their parental magmas. For example, the low contents of $(\mathrm{Ni}<122 \mathrm{ppm}),(\mathrm{Co}<43 \mathrm{ppm}), \mathrm{MgO}$ (average of 6.02\%) and $\mathrm{Mg \#}(<58)$ testify that the parental magmas would have undergone a significant fractionation of ferromagnesian minerals (Arth, 1976; Frey et al., 1978; Xu et al., 2001) within the magma chamber or as they ascend to the surface of the earth's crust. The negative correlation in $\mathrm{P}_{2} \mathrm{O}_{5}$ would be compatible with the presence of apa- 
tite which was unfortunately not observed in thin sections. The decrease in $\mathrm{Al}_{2} \mathrm{O}_{3}$ and $\mathrm{Sr}$ contents is the result of the significant fractionation of plagioclase feldspars. The continuous decrease in $\mathrm{Fe}_{2} \mathrm{O}_{3}$ and $\mathrm{TiO}_{2}$ associated with regularly decrease in Mgo, indicates a stage of fractionation of Fe-Ti oxides during the evolution of the magma. The crystallization of clinopyroxene is characterized by a decrease in $\mathrm{CaO}$ (Figure 6(i)), Sc and $\mathrm{Cr}$ (Figure 7(a), (c)) concentrations at decreasing $\mathrm{MgO}$ contents. $\mathrm{La} / \mathrm{Sm}$ vs. La diagram (Figure 9(a)) show nearly linear trend expressing fractional crystallization and high gradient lines demonstrating partial melting (Stephen, 2006). Despite a relative dispersion of the data in some cases, the different plots show an almost linear positive correlation between the incompatible elements (Figures 9 (b)-(d)). The $\mathrm{Nb}$ vs. $\mathrm{La}, \mathrm{Zr}$ and $\mathrm{Rb}$ diagrams of mafic magmatic rocks in the study area suggest an alignment of points on a line passing through the origin. On the other hand, lines not passing through the origin reflect the evolution of magmas from multiple sources and/or variable modalities of magmatic mixtures or crustal contamination. The behavior of the data in these different diagrams confirms that the hypovolcanic rocks of Figuil and Léré evolved through fractional crystallization. The collinear variations of the trace elements also indicate the probable development of fractional crystallization processes operating in more or less enriched and/or contaminated mantel-derived magmas.

\subsection{Crustal Contamination}

In the $\mathrm{Th} / \mathrm{Yb}$ vs. $\mathrm{Ta} / \mathrm{Yb}$ diagram of Pearce (1982) (Figure 10(a)) the samples are cluster at the initial point of the fractional crystallization process. They plot within the mantle array and seem to have a positive correlation similar to that of
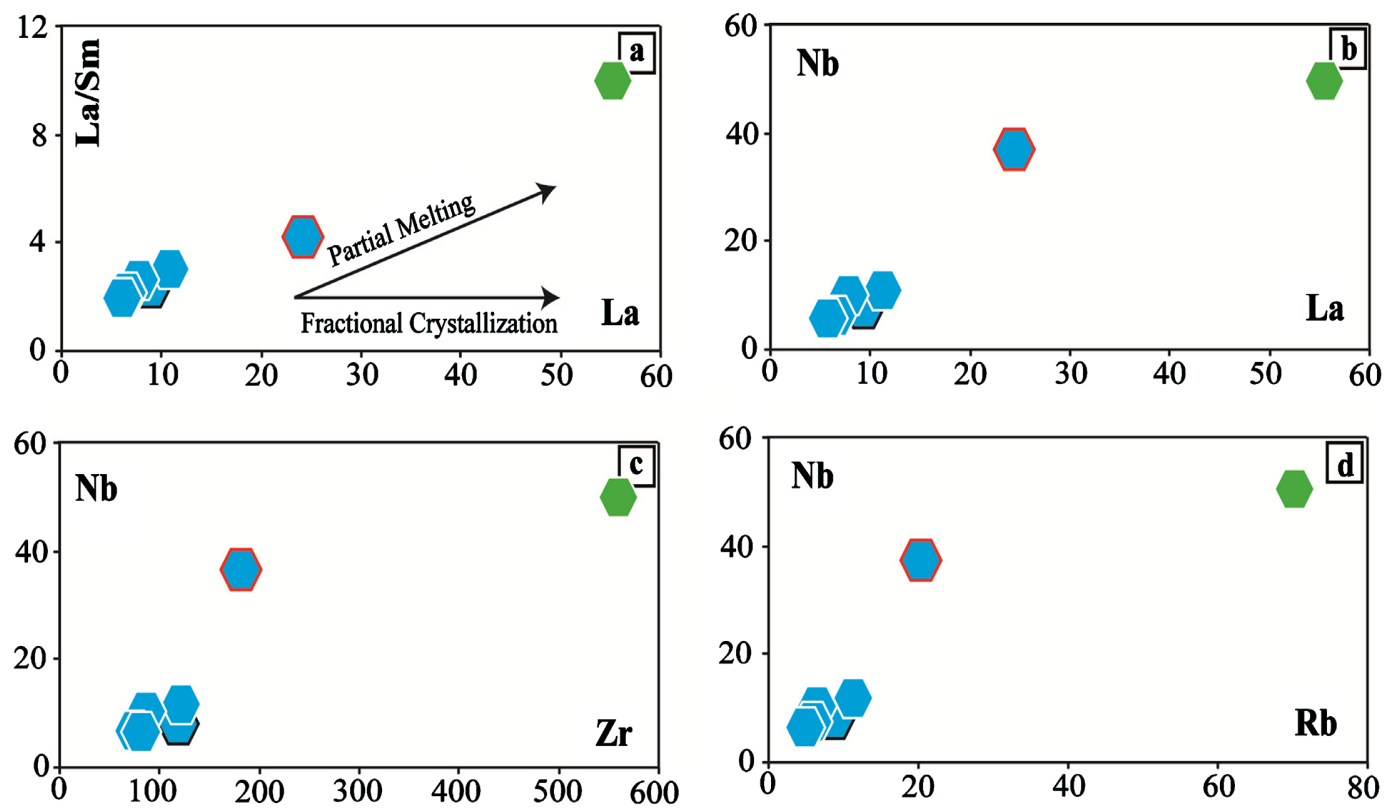

Figure 9. (a) La/Sm vs. La diagram showing the characterization of geologic processes of the studied diorites. ((b), (c)) Illustration of fractional crystallization using incompatible elements. 

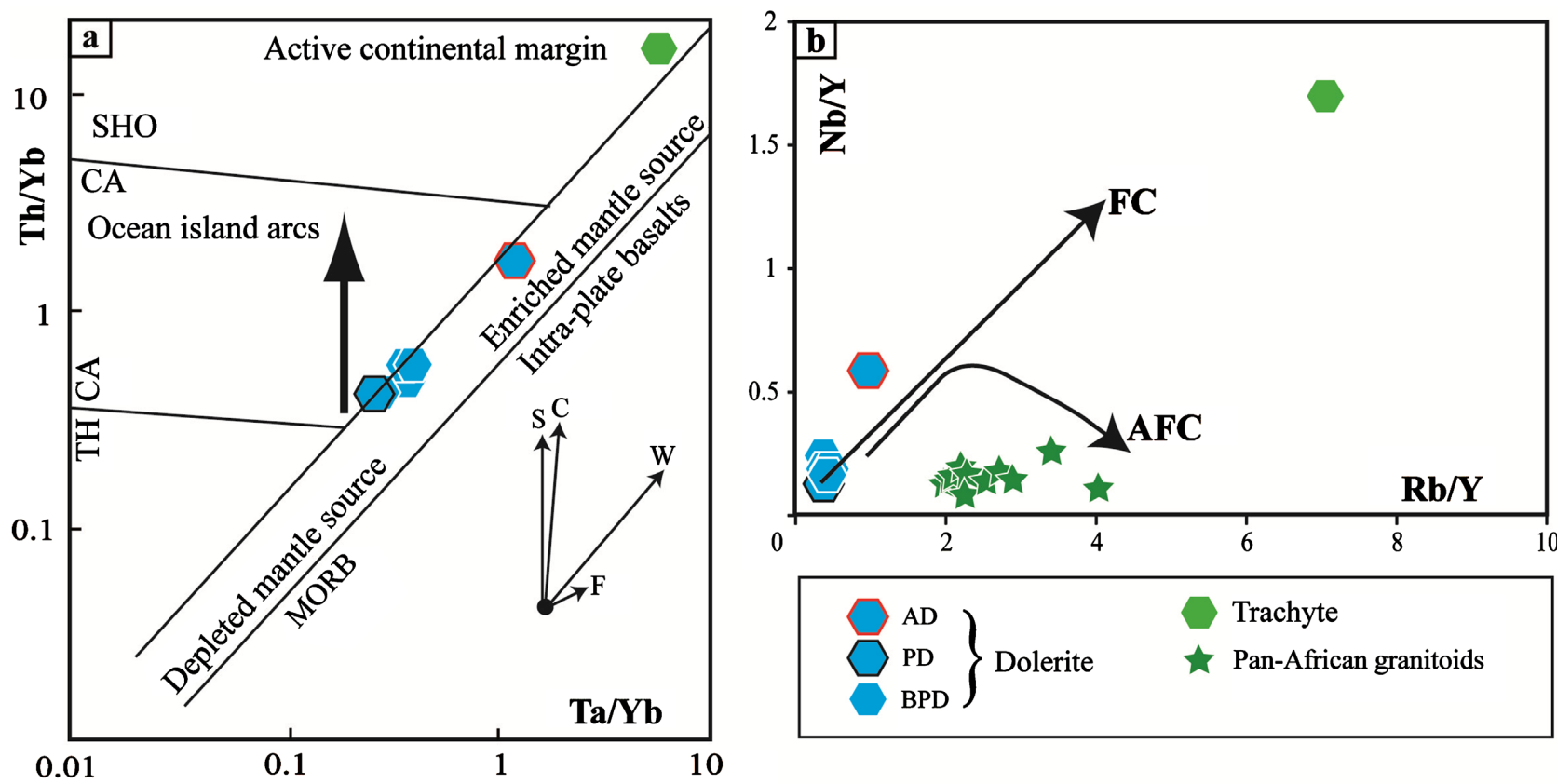

Figure 10. (a) Th/Yb vs. Ta/Yb diagram after Pearce (1982) applied to studied dolerites; CA: calc-alkaline, SHO: shoshonite, TH: tholeiitic basalts. The vectors S, C, W and F refer to subduction zone, crustal contamination, intra plate fractionation, and fractional crystallization respectively according to Pearce (1982). (b) Nb/Y vs. Rb/Y diagram after Cox \& Hawkesworth (1985) and Leeman \& Hawkesworth (1986) showing basement samples relative to the dolerite compositions. Data for Precambrian basement are from Isseini et al. (2012).

uncontaminated lavas. The low effect of contamination by crustal fragments can be also evidenced in the $\mathrm{Rb} / \mathrm{Y}$ vs. Nb/Y diagram of Cox \& Hawkesworth (1985) and Leeman \& Hawkesworth (1986) (Figure 10(b)). In this diagram, the studied dolerites ( $\mathrm{Rb} / \mathrm{Y}: 0.36$ - 0.97) are plotted far from Pan-African granitoids' samples (Rb/Y: 1.95 - 4.01) suggesting the minor impact of the crustal assimilation compared to the fractional crystallization on magma compositions.

The dolerite samples chemical compositions also show $\mathrm{Nb} / \mathrm{U}(28.33$ - 47.00), $\mathrm{La} / \mathrm{Nb}(0.65-1.55)$, and $\mathrm{Th} / \mathrm{Nb}(0.06-0.10)$ ratios like those of MORB characterized by high values of the $\mathrm{Nb} / \mathrm{U}$ ratio $(>45)$ and low values of the $\mathrm{La} / \mathrm{Nb}$ ratio $(0.8-1.1)$ and $\mathrm{Th} / \mathrm{Nb}(<0.1)$ (Sun \& McDonough, 1989; Hofmann et al., 1986; Hollanda et al., 2006), and far from the continental crust that has a low value of the ratio $\mathrm{Nb} / \mathrm{U}(4.4-25)$ and high values of the ratios of $\mathrm{La} / \mathrm{Nb}(1.6-2.6)$ and $\mathrm{Th} / \mathrm{Nb}(0.24-0.88)$ according to Rudnick et al. (2003). These features indicate a negligible effect of crustal contamination. The positive $\mathrm{Nb}-\mathrm{Ta}$ anomalies $\left(\mathrm{Nb} / \mathrm{Nb}^{*}: 1.04-1.25\right)$ in all dolerites also signify the nonexistence of contamination by crustal materials.

\subsection{Mantle Source and Melting}

Given that the magma migrated through continental basement rocks, consequently the origin of the dolerites and trachyte from the melting of the continental Pan African granitoids cannot be excluded. However, trace elements ratios, principally incompatible ones, $\mathrm{Ba} / \mathrm{Nb}$ and $\mathrm{Rb} / \mathrm{Zr}$ (LILE/HFSE) are superior 

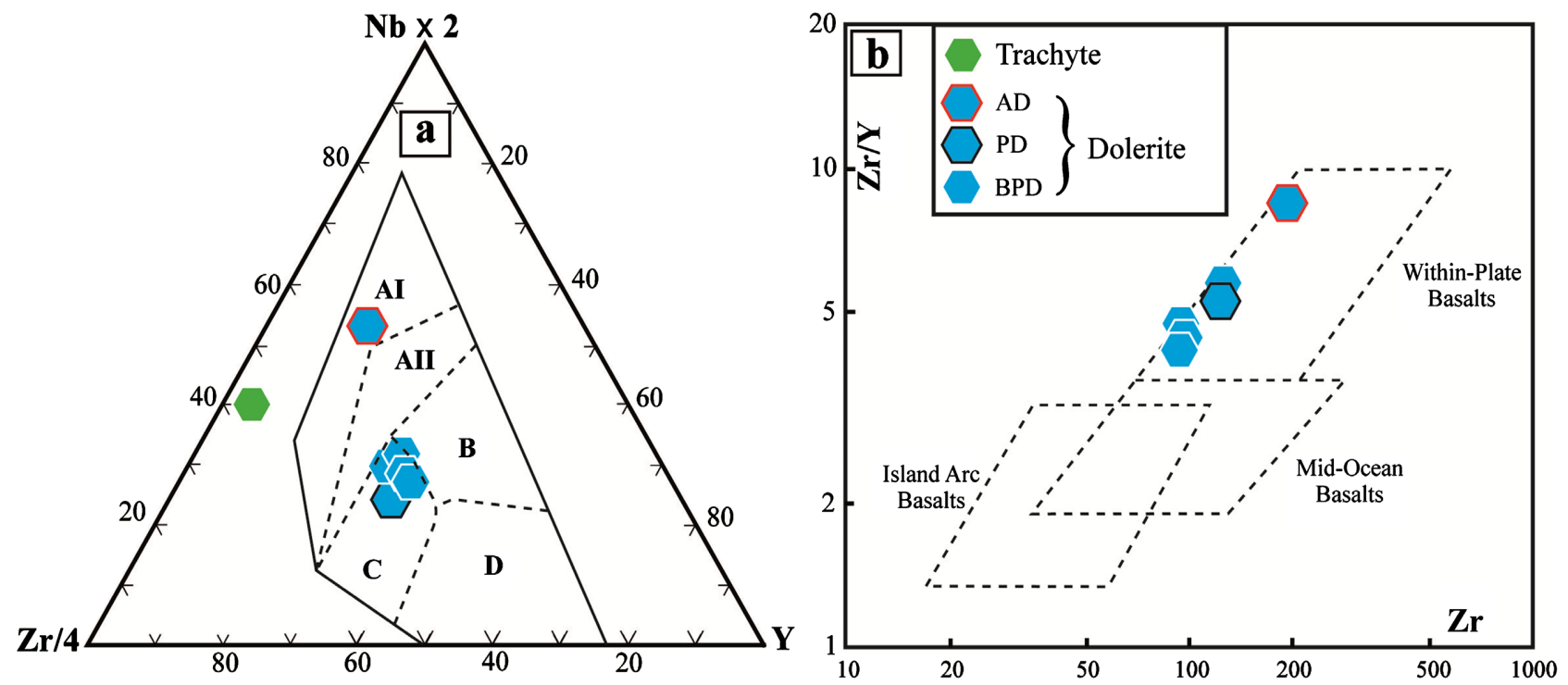

Figure 11. (a) $\mathrm{Zr} / 4$ - 2Nb-Y triangular diagram of Meschede (1986) showing the geotectonic context of mafic magmatic rocks of Figuil and Léré dolerites and trachytes. AI: Within-plate alkali basalts; AII: Within-plate alkali basalts and Within-plate tholeiite; B: E-type MORB; C: Within-plate tholeiite and volcanic arc basalt; D: N-type MORB and volcanic arc basalt. (b) Zr/Y vs. Zr diagram of basaltic rocks (Pearce \& Norry, 1979) showing the location of the mafic magmatic rocks studied in the field of whithin plate basalts. 
(55.78) is not classified. Continental tholeiites were also identified in other localities in Cameroon and Chad (crosscutting the Pan-African basement) at Figuil and Léré (Klamadji et al., 2020), Mayo Oulo-Léré and Babouri-Figuil (Ngounouno et al., 2001), Balché and Mangbaï (Béa et al., 1990), Biden (Vicat et al., 2001), Dschang, Bangangté and Manjo (Tchouankoué et al., 2012), Mbaoussi (Nkouandou et al., 2016), Bafoussam (Kouankap Nono et al., 2013).

\section{Conclusion}

The chemical study of studied dykes shows that mafic samples (dolerites) are predominantly basaltic in composition, while the felsic one is trachytic. Based on the mineralogical geochemical compositions, three groups of dolerites are identified: the pyroxene bearing dolerites (PD) and biotite and pyroxene bearing dolerites (BPD) are sub-alkaline while amphibole bearing dolerites (AD) and trachyte are alkaline. The rocks of the studied area have an evolution dominated by a fractional process with negligible impact of the crustal contamination characterized by low $\mathrm{Rb} / \mathrm{Y}$ ratios for dolerites $(0.36-0.97)$ and high values of $\mathrm{Rb} / \mathrm{Y}$ for the Pan-African granitoids' samples (1.95 - 4.01). The nature of doleritic and trachytic magma sources is supported by their $(\mathrm{Tb} / \mathrm{Yb}) \mathrm{N}>1.9(1.91-3.79)$ and $\mathrm{Dy} / \mathrm{Yb}>2(2.32$ - 3.50) ratios of most samples, which suggests melting in a garnet-bearing mantle. Regarding the geodynamic and geotectonic context of the studied rocks, doleritic samples are classified as 1) Within-plate tholeiite and volcanic arc basalt; 2) Within-plate alkali basalts.

In the future, we plan to increase the number of analyzes in these dolerite formations in order to better characterize them geochemically. Isotopic data will be needed to better characterize the source of these rocks. In order to insert the dolerite dykes studied in the context of CPAC, radiogenic dating will be also necessary.

\section{Acknowledgements}

This paper is a part of doctoral research being done by Klamadji Moussa Ngarena. Boris Chako-Tchamabé and anonymous reviewers are thanked for useful remarks which helped us to improve the manuscript.

\section{Conflicts of Interest}

The authors declare no conflicts of interest regarding the publication of this paper.

\section{References}

Arth, J. G. (1976). Behavior of Trace Elements during Magmatic Processes-Summary of Theoretical Models and Their Applications. Journal of Research of the U.S. Geological Survey, 4, 41-47.

Atour, M. M., Bardinntzeff, J. M., Mefire, A. F., Nkouandou, O. F., Tchameni, R., \& Dinamou, A. (2020). Petrology and Geochemical Framework of Dolerites Dykes of Temté, North Cameroon, Central Africa. Acta Geochimica, 40, 287-299. 
https://doi.org/10.1007/s11631-020-00432-4

Béa, A. Cochemé, J. J., Trompette, R., Affaton, P., Soba, D., \& Sougy, J. (1990). Grabens d'âge paléozoïque inférieur et volcanisme tholéiitique associé dans la région de Garoua au Nord-Cameroun. Journal of African Earth Sciences, 10, 657-667.

https://doi.org/10.1016/0899-5362(90)90032-A

Bouyo, H. M., Zhao, Y., Penaye, J., Zhang, S. H., \& Njel, U. O. (2015). Neoproterozoï Subduction Related Metavolcanic and Metasedimentary Rocks from the Rey Bouba Greenstone Belt of North-Central Cameroon in the Central African Fold Belt: New Insights into a Continental Arc Geodynamic Setting. Precambrian Research, 261, 40-53. https://doi.org/10.1016/j.precamres.2015.01.012

Cabanis, B., \& Thiéblemont, D. (1988). La discrimination des tholéiites continentales et des basaltes arrière-arc; Proposition d'un nouveau diagramme, le triangle Th-3xTb-2xTa. Bulletin de la Société Géologique de France, 86, 927-935. https://doi.org/10.2113/gssgfbull.IV.6.927

Carmichael, I. S. E., Turner, F. J., \& Verhoogen, J. (1974). Modal and Chemical Compositions of the Granitic Rocks Related to the Major Molybdenum. Journal of the Geology Society of Japan, 77, 441-452. https://doi.org/10.5575/geosoc.77.441

Coulon, C., Vidal, P., Dupuy, C., Popoff, B., Popoff, M., Maluski, H., \& Hermitte, D. (1996). The Mesozoic to Early Cenozoic Magmatism of the Benue Trough (Nigeria); Geochemical Evidence for the Involvement of the St Helena Plume. Journal of Petrology, 34, 1341-1358. https://doi.org/10.1093/petrology/37.6.1341

Cox, K. G., \& Hawkesworth, C. J. (1985). Relative Contribution of Crust and Mantle to Flood Basalt Magmatism, Mahabaleshwar, Deccan Traps. Philosophical Transactions of the Royal Society A, 310, 627-641. https://doi.org/10.1098/rsta.1984.0011

Dawaï, D. (2014). Les plutons de Guider et de Bossoum-Pologozom (Chaîne Panafricaine au Nord du Cameroun): Analyse pétrographique, structurale, magnétique et géochronologique et implication géodynamique. Thèse de Doctorat en Géosciences. Environnement, Université de Toulouse, $260 \mathrm{p}$.

Dejax, J., \& Brunet, M. (1996). Les flores fossiles du bassin d'Hama-koussou, Crétacéinférieur du Nord-Cameroun: Corrélations biostratigraphiques avec le fossé de la Bénoué, implications paléogéographiques. Bulletin des Centres de Recherches Exploration-Production Elf-Aquitaine, 16, 145-173.

Floyd, P. A., \& Winchester, J. A. (1975) Magma Type and Tectonic Setting Discrimination Using Immobile Elements. Earth and Planetary Science Letters, 27, 211-218. https://doi.org/10.1016/0012-821X(75)90031-X

Frey, F. A., Green, D. H., \& Roy, S. D. (1978). Integrated Models of Basalt Petrogenesis: A Study of Quartz Tholéiites to Olivine Melilitites from South Eastern Australia Utilizing Geochemical and Experimental Petrological Data. Journal of Petrology, 19, 463-513. https://doi.org/10.1093/petrology/19.3.463

Halls, H. C. (1987). Introduction. In H. C. Halls, \& W. F. Fahrig (Eds.), Mafic Dyke Swarms (pp. 1-3). Geological Association of Canada.

Hofmann, A. W., Jochum, K. P., Seufert, M., \& White, W. M. (1986). Nb and Pb in Oceanic Basalts: New Constraints on Mantle Evolution. Earth and Planetary Science Letters, 79, 33-45. https://doi.org/10.1016/0012-821X(86)90038-5

Hollanda, M. H. B. M., Pimentel, M. M., Custodio Oliveira, D., \& Jardim de Sa, E. F. (2006). Lithosphere-Asthenosphere Interaction and the Origin of Cretaceous Tholeiitic Magmatism in Northeastern Brazil: Sr-Nd-Pb Isotopic Evidence. Lithos, 86, 34-49. https://doi.org/10.1016/j.lithos.2005.04.004

Huang, Q., Zheng, H., Sun, X., Yang, Q., Cai, Z., \& Xia, B. (2021). Compositional Signatures of Dolerite Dykes from the Purang Ultramafic Massif, Tibet: Implications for 
Garnet-Bearing Components in the Neo-Tethyan Mantle. Lithos, 392-393, Article ID: 106157. https://doi.org/10.1016/j.lithos.2021.106157

Irvine, T. N., \& Baragar, W. R. (1971). A Guide to the Chemical Classification of Common Volcanic Rocks. Canadian Journal of Earth Sciences, 8, 523-548.

https://doi.org/10.1139/e71-055

Isseini, M., André-Mayer, A. S., Vanderhaeghe, O., Barbey P., \& Deloule, E. (2012). A-Type Granites from the Pan-African Orogenic Belt in Southwestern Chad Constrained Using Geochemistry, Sr-Nd Isotopes and U-Pb Geochronology. Lithos, 153, 39-52. https://doi.org/10.1016/j.lithos.2012.07.014

Jung, C., Jung, S., Hoffer, E., \& Berndt, J. (2006). Petrogenesis of Tertiary Mafic Alkaline Magmas in the Hocheifel, Germany. Journal of Petrology, 47, 1637-1671. https://doi.org/10.1093/petrology/egl023

Klamadji, M. N., Gountié Dedzo, M., Tchameni, R., \& Dawaï, D. (2020). Petrography and Geochemical Characterization of Dolerites from Figuil (Northern Cameroon) and Léré (Southwestern Chad). International Journal of Geosciences, 11, 459-482. https://doi.org/10.4236/ijg.2020.117023

Kouankap Nono, G. D., Wotchoko, P., Ganno, S., Ngong Njinchuki, D., Nzenti, J. P., \& Suh Cheo, E. (2013) Petrochemical Characterization of Two Distinct Types of Dolerites from Bafoussam Area, West Cameroon. International Journal of Geosciences, 4, 1131-1144. https://doi.org/10.4236/ijg.2013.48107

Le Bas, M. J., Le Maitre, R. W., Streckeisen, A., \& Zanettin, B. (1986). A Chemical Classification of Volcanic Rocks Based on the Total Alkali-Silica Diagram. Journal of Petrology, 27, 745-750. https://doi.org/10.1093/petrology/27.3.745

Leeman, W. P., \& Hawkesworth, C. J. (1986). Open Magma System: Trace Element and Isotopic Constraints. Journal of Geophysical Research: Solid Earth, 91, 5901-5912. https://doi.org/10.1029/JB091iB06p05901

Maurin, J. C., \& Guiraud, R. (1990). Relationships between Tectonics and Sedimentation in the Barremo-Aptian Intracontinental Basins of Northern Cameroon. Journal of African Earth Sciences, 10, 331-340. https://doi.org/10.1016/0899-5362(90)90064-L

Meschede, M. (1986). A Method of Discriminating between Different Types of Mid-Ocean Ridge Basalts and Continental Tholeiites with Nb-Zr-Y Diagram. Chemical Geology, 56, 207-218. https://doi.org/10.1016/0009-2541(86)90004-5

Miyashiro, A. (1974) Volcanic Rocks Series in Island Arcs and Active Continental Margins. American Journal of Science, 274, 321-355. https://doi.org/10.2475/ajs.274.4.321

Ngounouno, I., Déruelle, B., Guiraud, R., \& Vicat, J. P. (2001). Magmatismes tholéiitique et alcalin des demi-grabens crétacés de Mayo Oulo-Léré et de Babouri-Figuil (Nord du Cameroun-Sud du Tchad) en domaine d'extension continentale. Comptes Rendus de I'Académie des Sciences-Series IIA-Earth and Planetary Sciences, 333, 201-207. https://doi.org/10.1016/S1251-8050(01)01626-3

Nkouandou, O. F., Bardintzeff, J. M., Dourwe, P., Dogsaye, I., \& Fagny, M. A. (2016). Geochemistry and Petrogenesis of Mafic Doleritic Dykes at Mbaoussi (Adamawa Plateau, Cameroon, Central Africa). Journal of Geography, Environment and Earth Science International, 8, 1-18. https://doi.org/10.9734/JGEESI/2016/28198

Nkouandou, O. F., Bardintzeff, J. M., Mahamat, O., Mefire, A. F., \& Ganwa, A. A. (2017). The Dolerites Dyke Swarm of Mongo, Guéra Massif (Chad, Central Africa): Geological Setting, Petrography and Geochemestry. Open Geosciences, 9, 138-150.

https://doi.org/10.1515/geo-2017-0012

Nkouandou, O. F., Bardintzeff, J. M., Mefire, A. F., \& Bardintzeff, J. M. (2015). Petrology and Geochemistry of Doleritic Dyke of Likok (Cameroon, Central Africa). Carpathian Journal of Earth and Environmental Sciences, 10, 121-132. 
Pearce, J. A. (1982). Trace Elements Characteristics of Lavas from Destructive Plate Boundaries. In R. S. Thorpe, Ed., Andesite (pp. 525-548). John Wiley and Sons.

Pearce, J. A., \& Norry, M. J. (1979). Petrogenetic Implications of Ti, Zr, Y and Nb Variations in Volcanic Rocks. Contributions to Mineralogy and Petrology, 69, 33-47. https://doi.org/10.1007/BF00375192

Rudnick, R. L., Gao, S., Holland, H. D., \& Turekian, K. K. (2003). Composition of the Continental Crust. Treatise on Geochemistry, 3, 1-64. https://doi.org/10.1016/B0-08-043751-6/03016-4

Schwoerer, P. (1965). Carte géologique de reconnaissance à l'échelle du 1/500 000: Notice explicative sur la feuille Garoua-Est, Dir. Mines Géol. Impr. Nationale.

Silpa, A. S., Satish-Kumar, M., \& Takahashi, T. (2021). Sr-Nd Isotopic Study of Dolerite Dykes in the Western Dharwar Craton, Southern India: Implications for the Evolution of the Subcontinental Lithospheric Mantle in Late Archean. Lithos, 388-389, Article ID: 106023. https://doi.org/10.1016/j.lithos.2021.106023

Srivastava, R. K. (2011). Dyke Swarms: Keys for Geodynamic Interpretation. SpringerVerlag. https://doi.org/10.1007/978-3-642-12496-9

Stephen, A. N. (2006) Structure of the Earth and the Origin of Magmas. Tulane University.

Sun, S. S., \& McDonough, W. F. (1989). Chemical and Isotopic Systematics of Oceanic Basalts: Implications for the Mantle Composition and Processes. In: Saunders, A.D., Norry, M.J. IEds.), Magmatism in the Ocean Basins. Geological Society, London, Special Publication, 42, 313-345. https://doi.org/10.1144/GSL.SP.1989.042.01.19

Tchouankoué, J. P., Simeni Wambo, A. N., Kagou Dongmo, A., \& Worner, G. (2012). Petrology, Geochemistry, and Geodynamic Implications of Basaltic Dyke Swarms from the Southern Continental Part of the Cameroon Volcanic Line, Central Africa. The Open Geology Journal, 6, 72-84. https://doi.org/10.2174/1874262901206010072

Tchouankoué, J. P., Simeni Wambo, N. A., Kagou Dongmo, A., \& Li, X. H. (2014). ${ }^{40} \mathrm{Ar} /{ }^{39} \mathrm{Ar}$ Dating of Basaltic Dykes Swarm in Western Cameroon: Evidence of Late Paleozoic and Mesozoic Magmatism in the Corridor of the Cameroon Line. Journal of African Earth Sciences, 93, 14-22. https://doi.org/10.1016/j.jafrearsci.2014.01.006

Toteu, S. F. (1990). Geochemical Characterization of the Main Petrographical and Structural Units of Northern Cameroon, Implication for Pan-African Evolution. Journal of African Earth Sciences, 10, 615-624. https://doi.org/10.1016/0899-5362(90)90028-D

Toteu, S. F., Michard, A., Bertrand, J. M., \& Rocci, G. (1987). U/Pb Dating of Precambrian Rocks from Northern Cameroon, Orogenic of the Pan-African Belt of Central Africa. Precambrian Research, 37, 71-87. https://doi.org/10.1016/0301-9268(87)90040-4

Vicat, J. P., Ngounouno, I., \& Pouclet, A. (2001). Existence de dykes doléritiques anciens à composition de tholéiites continentales au sein de la province alcaline de la ligne du Cameroun: Implication sur le contexte géodynamique. Comptes Rendus de l'Académie des Sciences-Series IIA-Earth and Planetary Science, 332, 243-249.

https://doi.org/10.1016/S1251-8050(01)01526-9

Wacrenier, P. (1952). Rapport de fin mission Garoua-Laï. Direction des mines. A.E.F., 24 p.

Wang, K., Plank, T., Walker, J. D., \& Smith, E. I. (2002). A Mantle Melting Profile across the Basin and Range, SW USA. Journal of Geophysical Research: Solid Earth, 107, ECV51-EVC5-21. https://doi.org/10.1029/2001JB000209

Xu, Y., Chung, S. L., Jahn, B., \& Wu, G. (2001). Petrologic and Geochemical Constraints on the Petrogenesis of Permian-Triassic Emeishan Flood Basalts in Southwestern China. Lithos, 58, 145-168. https://doi.org/10.1016/S0024-4937(01)00055-X 